\title{
The influence of habitat, season and tidal regime in the activity of the intertidal crab Neohelice (=Chasmagnathus) granulata
}

\author{
Tomás Luppi · Claudia Bas • Agustina Méndez Casariego • Mariano Albano • \\ Juan Lancia • Marcelo Kittlein · Alan Rosenthal • Nahuel Farías • \\ Eduardo Spivak · Oscar Iribarne
}

Received: 3 August 2011 / Revised: 14 March 2012 / Accepted: 24 March 2012 / Published online: 12 April 2012

(C) Springer-Verlag and AWI 2012

\begin{abstract}
The activity pattern of intertidal crabs is influenced by factors that usually change rhythmically following tidal and/or diel cycles, and is often associated with the use of refuges. The movement activity of the burrowing crab Neohelice granulata was compared among three populations from SW Atlantic coastal areas where they face different tidal regimes, water salinities, substrata and biological factors. At each site, we examined the seasonal activity of the crabs (individuals collected in pitfall traps) in two types of habitat: mudflat and salt marsh. The working
\end{abstract}

Communicated by Martin Thiel.

Electronic supplementary material The online version of this article (doi:10.1007/s10152-012-0300-9) contains supplementary material, which is available to authorized users.

T. Luppi $(\square) \cdot$ C. Bas · M. Albano · J. Lancia · A. Rosenthal · N. Farías · E. Spivak

Laboratorio de Invertebrados, Facultad de Ciencias Exactas y Naturales, Instituto de Investigaciones Marinas y Costeras (IIMyC), Universidad Nacional de Mar del Plata and Consejo Nacional de Investigaciones Científicas y Tecnológicas (CONICET), Funes 3350, 7600 Mar del Plata, Argentina e-mail: taluppi@mdp.edu.ar

\section{A. Méndez Casariego · O. Iribarne}

Laboratorio de Ecología, Facultad de Ciencias Exactas y Naturales, Instituto de Investigaciones Marinas y Costeras (IIMyC), Universidad Nacional de Mar del Plata and Consejo Nacional de Investigaciones Científicas y Tecnológicas (CONICET), CC 573 Correo Central, B7600WAG Mar del Plata, Argentina

\section{Kittlein}

Laboratorio de Ecofisiología, Facultad de Ciencias Exactas y Naturales, Instituto de Investigaciones Marinas y Costeras (IIMyC), Universidad Nacional de Mar del Plata and Consejo Nacional de Investigaciones Científicas y Tecnológicas (CONICET), Funes 3350, 7600 Mar del Plata, Argentina hypothesis is that the activity would vary according to the diverse environmental conditions encountered at geographical and local scales. Crab activity varied between sites and seasons showing to be more intense when habitats were covered by water. The most active groups were large males, followed by large non-ovigerous females. Ovigerous females were almost inactive. Most crabs were near or inside burrows at low tides in Mar Chiquita and Bahía Blanca, but they were active at both low and high tides in San Antonio during spring and summer. N. granulata were active in a wide range of temperatures: from 10 to $37^{\circ} \mathrm{C}$ at low tides and at temperatures as low as $2{ }^{\circ} \mathrm{C}$ when covered by water. Differences of activity between mudflat and salt marsh varied among sites depending on flooding frequencies. Movement activity of $N$. granulata varied both in space and in time; crabs move under very different abiotic conditions (e.g., low or high tide, daylight or night, low and high temperature) and their movement may also be prevented or elicited by biotic conditions like burrow complexity, food quality and predation pressure. The wide set of conditions under which $N$. granulata can be active may explain why this is the only semiterrestrial crab inhabiting latitudes higher than $40^{\circ} \mathrm{S}$ in South America.

Keywords Activity pattern - Intertidal crab · Inter-population differences $\cdot$ Neohelice granulata . Argentina

\section{Introduction}

The activity pattern of intertidal crabs is influenced by many different physical and biological factors that usually change rhythmically following tidal and/or diel cycles (Palmer 1995; Thurman 2004; Naylor 2005). These crabs 
may be active at high tides, low tides or both, and during the day, the night or both on the basis of (1) the morphological, physiological and behavioral traits that allow them to cope with the environment (e.g., resist dehydration, construct burrows, hide under refuges, respire or move more efficiently either in the air or in the water; Wolcott 1988), and (2) the ecological context (e.g., the presence of aerial or aquatic predators that feed during low or high tide; Dumas and Witman 1993; Christy 2007; Hines 2007). Within a species, the pattern may vary at local scales: crabs may be restricted to a narrow area in the intertidal zone where all individuals experience similar conditions (e.g., Ferreira Silva et al. 2009) or the population might be spread across different tidal levels and exposed to diverse sets of conditions in each one (emersion- submersion periods; e.g., Brousseau et al. 2002). At a larger scale, in species with broad distributional ranges that are exposed to different tidal regimes, the activity pattern will change depending on the importance of tide as a factor entraining activity rhythms (e.g., Abelló et al. 1991).

The activity pattern of intertidal crabs is associated with the use of refuges (e.g., burrows, crevices) ranging from species that remain hidden for long periods, with virtually no ambulatory activity except short expeditions (from centimeters to few meters), to those that perform long journeys (from meters to kilometers) within or between different areas of the intertidal zone, staying in refuges only for very short periods (Seiple and Mueller 1992; Vannini and Cannicci 1995). However, there are also species that occupy burrows for long periods and show both types of locomotion activities; the extent of their movements is related to reproduction, foraging or habitat exploration (Goshima et al. 1978; Nakasone et al. 1982). The main forces affecting the value of refuges in intertidal crabs are predation and environmental stress (Vannini and Cannicci 1995). As a result of these selective pressures, very different patterns of activity related to the use of refuge and tidal regimes have arisen in different species.

Ocypodidae (fiddler crabs and their allies, the intertidal crabs whose activity rhythms have been more intensely studied) are a very homogeneous group regarding the construction and use of refuges. They are active outside their burrows during low tides (Vannini and Cannicci 1995; Thurman 2004). Grapsoidea, in contrast, have received much less attention and their activity patterns seem to be more heterogeneous: many species are active during high tides and hide under stones, boulders or inside burrows when tides recede, but others are active at low tide (Table 1).

Neohelice granulata Dana, 1851, formerly known as Chasmagnathus granulatus (Grapsoidea, Varunidae), is endemic to the warm temperate coast of the southwestern Atlantic and strictly associated with tidal flats in estuaries, bays and coastal lagoons where the halophyte grasses Spartina spp. form marshes in the middle and/or upper intertidal zone (e.g., Boschi 1964; Spivak 2010). N. granulata digs semipermanent burrows and is active both in air and water (Iribarne et al. 1997; Halperin et al. 2000). During low tides, crabs leave burrows and perform "exploratory excursions" on mudflats between 5 and $15 \mathrm{~cm}$ from the entrance (Fathala et al. 2010a, b), but they hide in the presence of aerial predators (Maldonado 2002). Crabs are also active under water, carrying out longer excursions, especially during high tides, and their feeding activities rise dramatically during flooding in the vegetated habitat (D'Incao et al. 1992; Alberti et al. 2007a; Méndez Casariego et al. 2011a). Their reproduction is restricted to late spring and summer (Ituarte et al. 2004).

The habitat of these crabs includes different sets of environmental conditions at two spatial scales. Along its extensive but discontinuous geographical distribution $\left(\sim 22^{\circ}\right.$ latitude), they face different semidiurnal tide amplitudes (from few $\mathrm{cm}$ up to $9 \mathrm{~m}$ ), water salinities (from near 0 up to 60 ), substratum (from soft bottom to cobble beaches) and biological factors as Spartina species (Isacch et al. 2006) and different predators (e.g., Yorio et al. 2005). In addition, they live in contrasting habitats placed at different intertidal levels (mudflats and salt marshes); in both habitats, adults of both sexes and juveniles are intermixed (Spivak et al. 1994; Bas et al. 2005). The emersion-submersion pattern, burrow size, shape and dynamics, physical and chemical characteristics of water inside them, and feeding habits vary between these habitats (e.g., Iribarne et al. 1997; Botto and Iribarne 1999; Bortolus and Iribarne 1999).

The main goal of this study is to compare the locomotory activity of $N$. granulata among three SW Atlantic coastal areas selected on the basis of their difference in tidal regime, soil characteristics, salinity and relative height of the marsh. The working hypothesis is that the activity would vary according to the diverse environmental conditions encountered at two spatial scales: geographical and local. Using bidirectional pitfall traps to quantify the movements of crabs within and between habitats, the following specific questions were examined: Does the activity pattern of this species vary throughout their geographical distribution and along the year? Is the pattern or patterns of activity affected by rhythmic phenomena like tidal cycles (that vary in predictability and amplitude), circadian cycles or seasonal cycles? Are there any other environmental conditions, such as soil, salinity and marsh position that modulate these patterns?

\section{Materials and methods}

Study areas

The three selected sites form a southward gradient of increasing aridity and tidal amplitude (Fig. 1) also associated with 


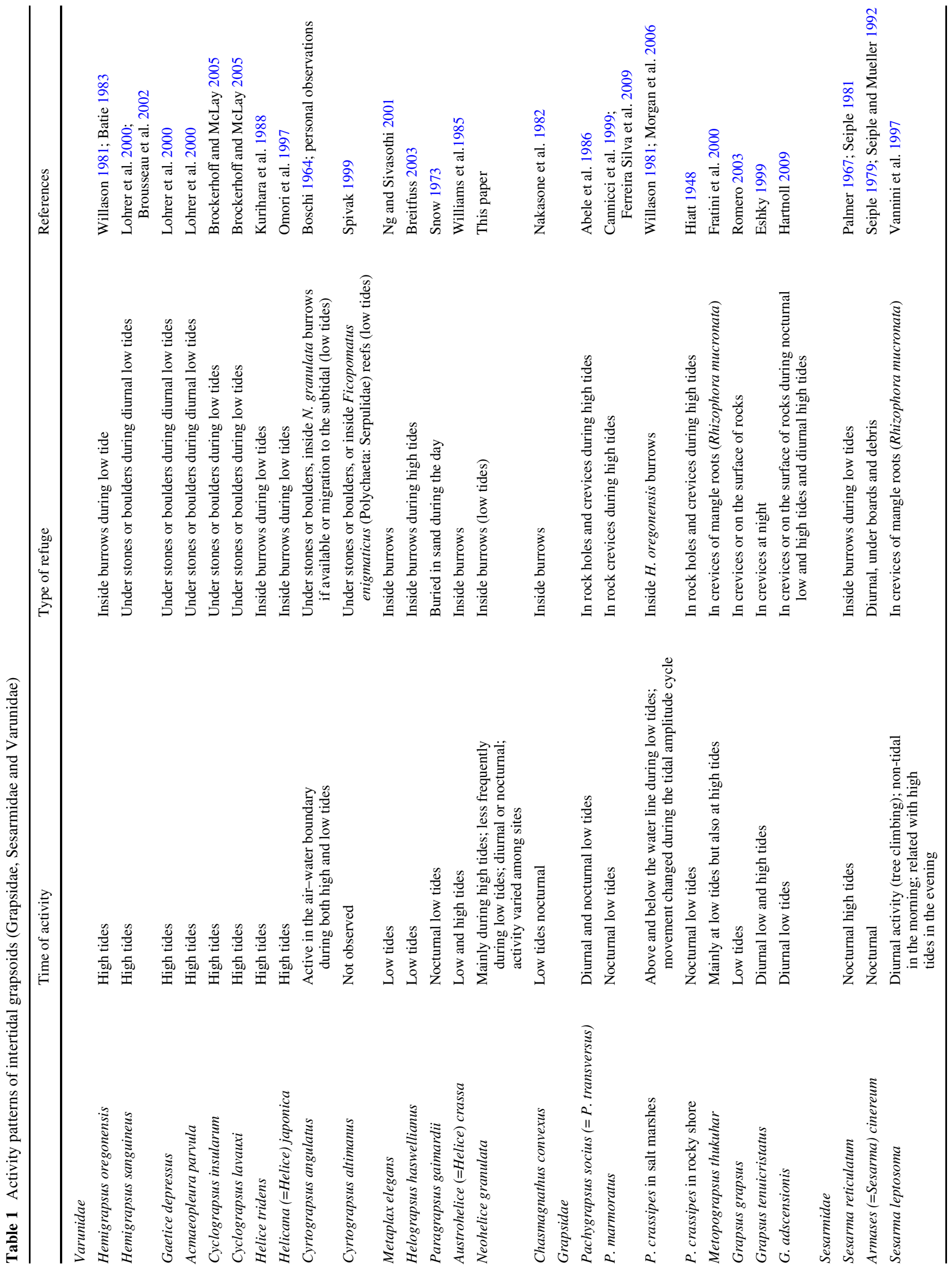


Fig. 1 Geographical position of sampling sites. Shadow zones indicates tidal regimen at each coastal region, microtidal $<2 \mathrm{~m}$, mesotidal $>2 \mathrm{~m}<4 \mathrm{~m}$, macrotidal $>4$ m (modified from Piccolo and Perillo 1997)

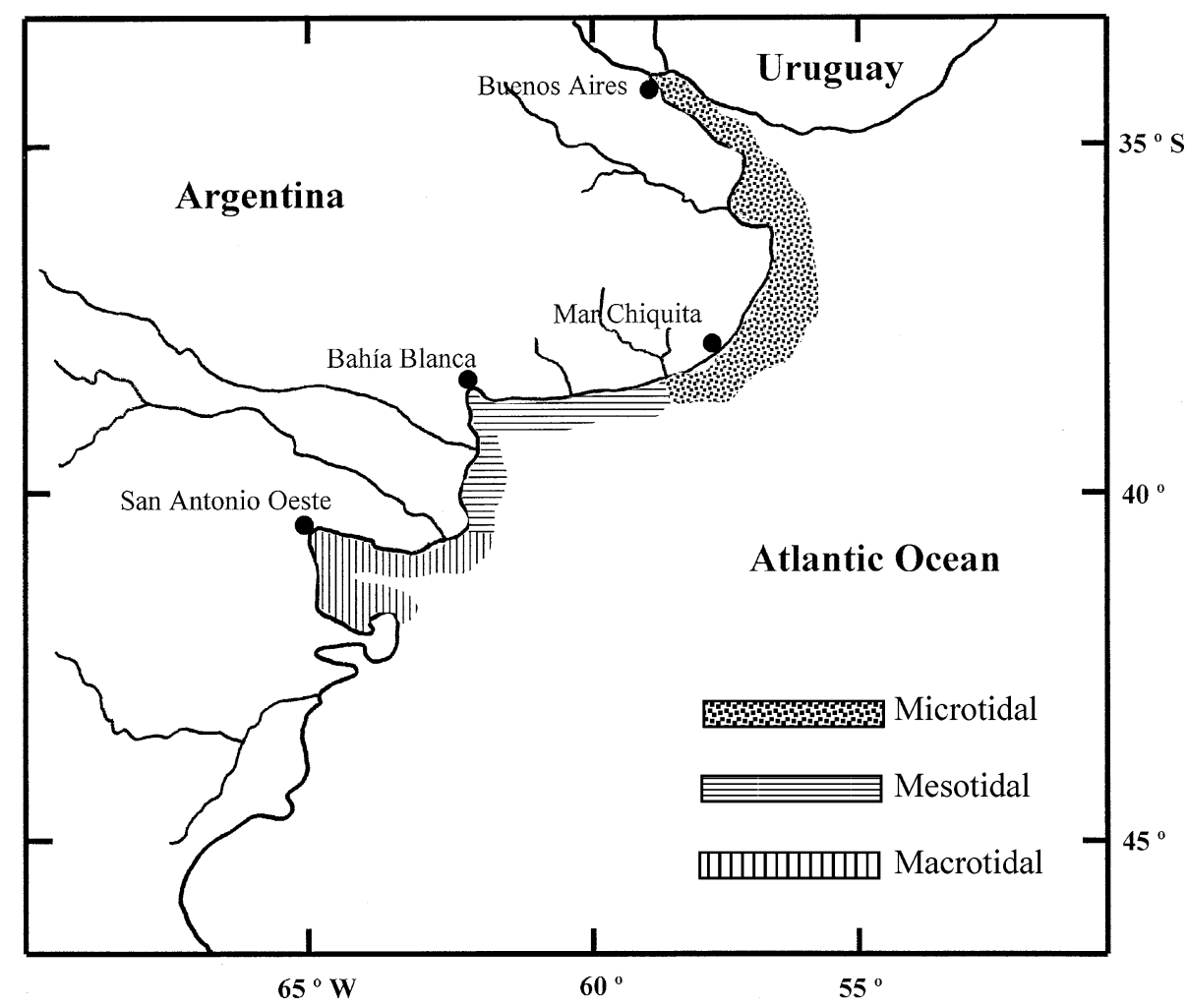

changes in the salt marsh communities (Isacch et al. 2006). From north to south, the sites were the following:

Mar Chiquita $\left(37^{\circ} 45^{\prime} \mathrm{S}, 57^{\circ} 19^{\prime} \mathrm{W}\right)$. This coastal lagoon $\left(46 \mathrm{~km}^{2}\right)$ with a semidiurnal microtidal regime $(0.3-1 \mathrm{~m}$ amplitude) is connected with the open sea by a narrow channel about $5 \mathrm{~km}$ long. The mean rainfall is $800 \mathrm{~mm} /$ year $^{-1}$. Tidal influence depends on the wind direction and intensity, tidal phase and freshwater runoff. The upper intertidal zone is a mixed Spartina densiflora and $S$. perennis marsh (Isacch et al. 2006), and the mid- and lower intertidal zones are mudflats. Sediments are fine with high penetrability and organic matter content (Fig. 2a, Spivak et al. 1994). Crabs occupy the upper- and middle intertidal zone. Burrows in the mudflat are shorter than in the salt marsh, where they reach more than $70 \mathrm{~cm}$ depth (Iribarne et al. 1997). In both areas, burrows reach the water table (Fanjul et al. 2008). Samples were taken in the $S$. densiflora marsh and in the mid-intertidal zone of the mudflat.

Bahía Blanca $\left(38^{\circ} 45^{\prime} \mathrm{S}, 62^{\circ} 15^{\prime} \mathrm{W}\right)$. This is a large estuary $\left(2,300 \mathrm{~km}^{2}, 1,550 \mathrm{~km}^{2}\right.$ of low-energy tidal flats). Rainfall is $650 \mathrm{~mm} /$ year $^{-1}$. The tidal regime is semidiurnal and mesotidal (up to $3.6 \mathrm{~m}$ amplitude, Servicio de Hidrografía Naval). Sediments are fine with high penetrability and organic matter content (Fig. 2b, Albano unpublished data). The intertidal area is characterized by an upper $S$. perennis marsh (Isacch et al. 2006), a mid-intertidal zone divided into a mudflat and a $S$. alterniflora marsh forming a narrow belt followed by the open low intertidal zone. Crabs are present in the upper- and mid-intertidal zones. Burrows from the mudflat range between 60 and $90 \mathrm{~cm}$ in length and those from the upper salt marsh are deeper, reaching $150 \mathrm{~cm}$ (Escapa et al. 2007); those in the S. alterniflora belt have not been described yet. The sampled area corresponded to the $S$. alterniflora marsh and the mudflat.

San Antonio $\left(40^{\circ} 46^{\prime} \mathrm{S}, 64^{\circ} 50^{\prime} \mathrm{W}\right)$. This bay $\left(80 \mathrm{~km}^{2}\right)$ opens to the San Matías Gulf and is located in a very dry area (average rainfall: $240 \mathrm{~mm}_{\text {year }}{ }^{-1}$ ) with no freshwater input. It has a semidiurnal macrotidal regime (up to $9 \mathrm{~m}$ amplitude, Servicio de Hidrografía Naval) (Fig. 1) with extensive sand-cobble intertidal flats. The upper intertidal zone is a Sarcocornia perennis marsh and the mid-intertidal zone divides into a Spartina alterniflora marsh (Isacch et al. 2006) and a mudflat that continues throughout the lower intertidal zone. Sediment organic matter content and penetrability are very low (Fig. 2c; Bas et al. 2005). Crab burrows occupy both the upper- and mid-intertidal zones, reaching up to $130 \mathrm{crabs}^{-2}$ (Bas et al. 2005). In both areas, burrows are shallow with a maximum depth of $10.5 \mathrm{~cm}$ (Sal Moyano et al. in press). Samples were taken in the $S$. alterniflora marsh and in the mudflat.

\section{Sampling program}

Samplings were performed seasonally, from July 2006 (winter) to June 2007 (autumn). In each study area, two habitats were selected: one in the salt marsh and one in 
Fig. 2 Schematic representation of each sampling site, a Mar Chiquita, b Bahía Blanca, c San Antonio. $O M$ organic matter content (in percentage), $G$ gravel (in percentage), $P$ penetrability ( $\mathrm{Kp} \mathrm{cm}^{-2}$; not available to $\left.\mathrm{BB}\right)$, dotted arrows with numbers indicate tidal height (in meters) necessary to cover the lower part of each mudflat and salt marsh (drawings not scaled)
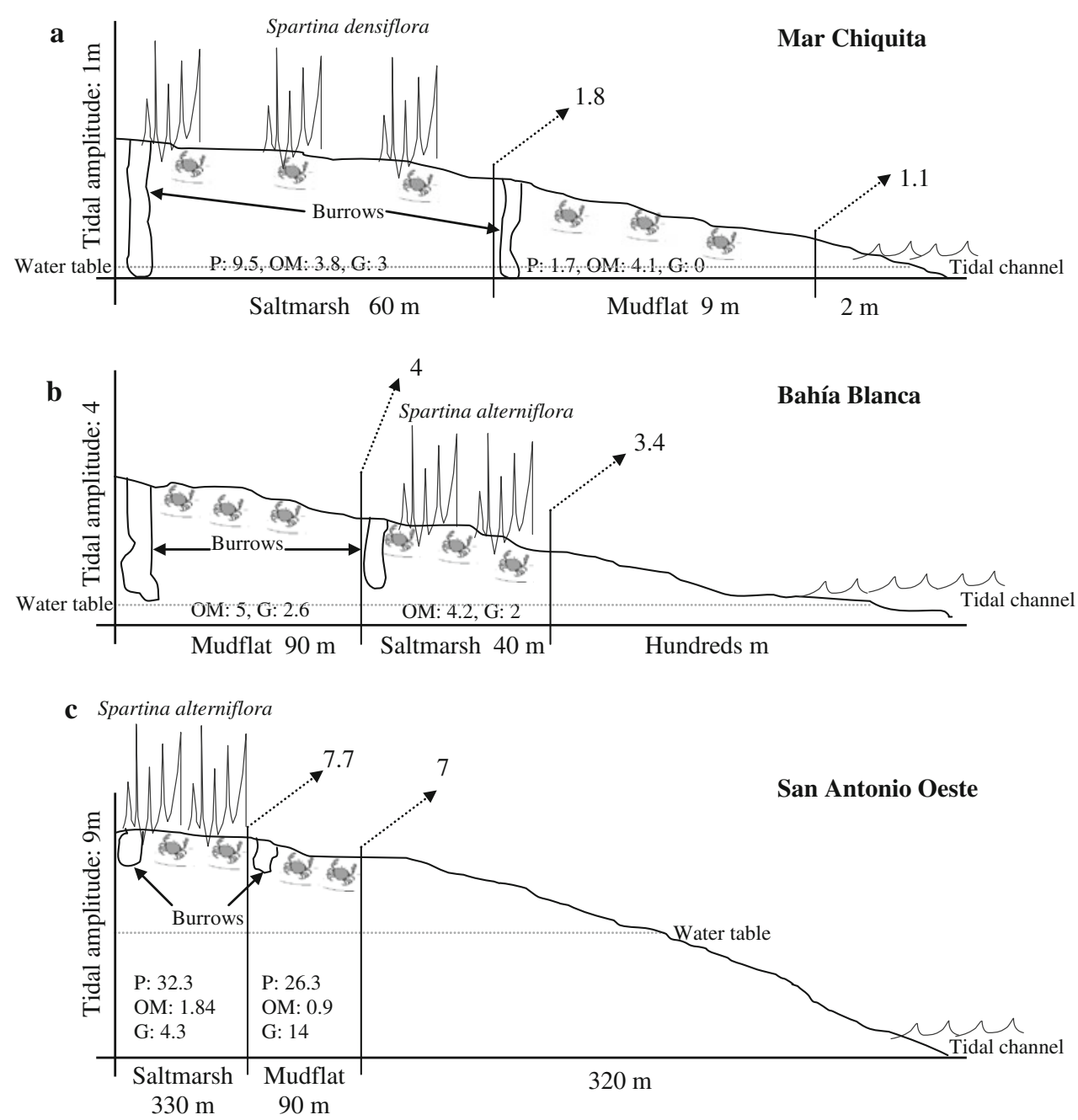

the mudflat. In each site, habitats selected were extensive in relation to the area covered by traps. During each season, the ambulatory activity of $N$. granulata, air temperature and moisture, and water temperature and salinity of burrows were measured in both habitats, in the middle of flooding ( $3 \mathrm{~h}$ before high tide) and ebbing ( $3 \mathrm{~h}$ after high tide), through a 48-h period. Consequently, there were 8 sets of data per habitat and season, obtained every $6 \mathrm{~h}$ approximately. Additional qualitative observations were made of burrow length and water retention during a tidal cycle in San Antonio and in the lower salt marsh of Bahía Blanca in order to draw a comparison with the other sites where the information is already available (see Iribarne et al. 1997; Escapa et al. 2007).

\section{Physical conditions of burrows, air and water}

At each site and habitat, five replicates of air temperature $\left(T_{\text {air }} ;{ }^{\circ} \mathrm{C}\right.$, accuracy $\left.\pm 1{ }^{\circ} \mathrm{C}\right)$ and moisture $5 \mathrm{~cm}$ above ground $\left(\mathrm{H}_{\text {air }} ; \%\right.$, accuracy $\pm 3 \%$ of scale $)$, and five repli- cates of temperature $\left(T_{\text {burrow }} ;{ }^{\circ} \mathrm{C}\right.$, accuracy $\left.\pm 0.1{ }^{\circ} \mathrm{C}\right)$ and salinity ( $\mathrm{S} ; \%$, accuracy $\pm 0.1 \%$ ) of water inside burrows were taken. Measurements were made by introducing sensors inside burrow openings until water completely covered the sensitive parts. If burrows were too dry or too deep (more than $70 \mathrm{~cm}$ ), water was not measured. Since air and water temperature and salinity varied broadly over a daily and seasonal pattern, only the range of temperature in absolute value $(\Delta \mathrm{T})$ and the salinity range $(\Delta \mathrm{S})$ were considered in comparisons. To evaluate the effect of water inside burrows in ameliorating extreme variations of temperature, $\Delta \mathrm{T}$ from air and burrows were compared for each habitat; at the same time, $\Delta \mathrm{S}$ of water from burrows were compared between habitats. As data from all sites and habitats together did not comply with normality and equal variance assumptions, even after transformation, comparisons were made for each site with a $t$-test for paired samples (Zar 2009).

A two-way ANOVA (Zar 2009) was used to analyze the differences in average values of moisture with habitat and 


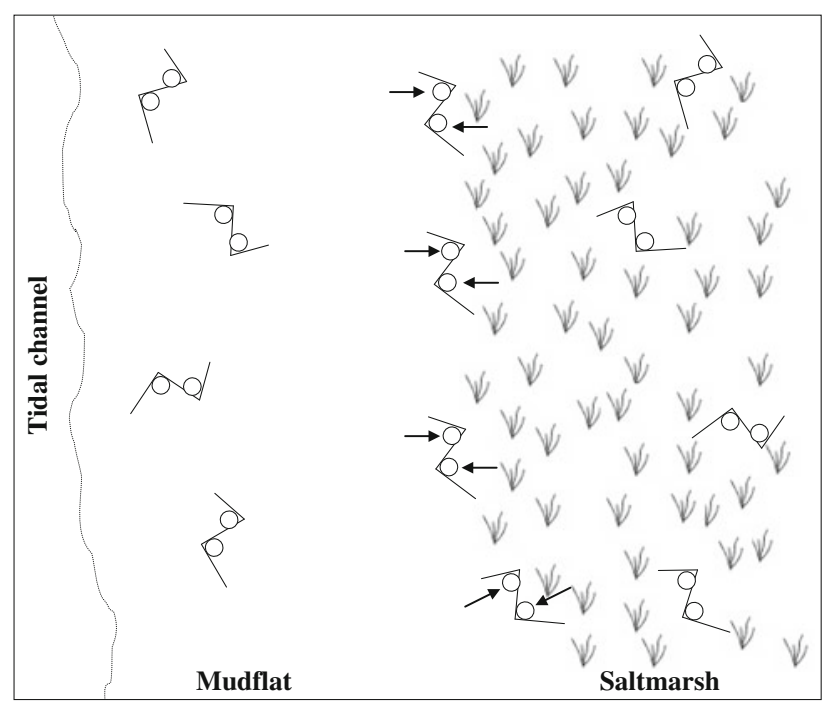

Fig. 3 Schematic representation of trap arrays in mudflat, salt marsh and interface between these habitats

sites as factors. Data were previously arcsin-transformed to comply with the assumptions.

\section{Relationship of activity with season, tide, habitat, and light}

Crab movements were quantified on the basis of the number of crabs caught in traps placed on mudflats, salt marshes and along the interface between both habitats. Each trap consisted of a drift fence of plastic mesh $0.30 \mathrm{~m}$ height and $1.5 \mathrm{~m}$ length, folded in three segments forming $120^{\circ}$ angles and vertically buried a few $\mathrm{cm}$ into the sediment. At each angle one pitfall trap $(18 \mathrm{~cm}$ diameter and $18 \mathrm{~cm}$ depth) was buried (Fig. 3). Crabs that reached the fences walked along them and fell down into the traps where they were retained. In mudflats and salt marshes, traps were oriented at any direction but at the interface between habitats, they were placed along the external edge of vegetated patches to discriminate crabs moving "into" and "out of" the marsh area (Fig. 3). Ten fences with two traps each were placed in the mudflat, ten in the salt marsh and ten in the border between the two habitats, with a minimum distance of $5 \mathrm{~m}$ between fences. Activity in each site was estimated as the average number of crabs per trap per tide.

Traps were checked every $6 \mathrm{~h}$, that is, when they were recently uncovered or just before they were again submerged by water. Crabs collected as soon as the intertidal zone emerged during the ebb represented those active during the previous high tide, when covered by water; crabs collected just before the water covered the zone again during the flood represented those active when uncovered by water during the previous low tide.
A generalized linear model was used to compare the activity between salt marsh and mudflat areas in each site, assuming a negative binomial distribution in the response variable (with variance greater than mean, function "glm.nb()" with a log-link in library "MASS" in the R 2.10.0 package [R Development Core Team 2008]), because crab numbers showed greater variability than that allowed in a Poisson model. The generalized linear model was formulated with season and habitat as factors and diurnal phase and tide as covariates. Two tidal states were considered: emersed or submersed, independently of the tidal phase, since in many cases high tides did not cover the sampled areas. The diurnal phase also had two states: daylight and dark depending on the light conditions prevailing at the moment of high or low tide. Based on the method developed by Gerhard et al. (2007), multiple comparisons of groups were made a posteriori to estimate confidence intervals for negative binomial distributed data.

\section{Sex and size of active crabs}

Additional samples were collected to estimate the size and sex composition of the population in each study site and habitat. These samples consisted of all crabs present at the surface and in burrows in ten areas delimited by square metal frames $\left(0.25 \mathrm{~m}^{2}\right)$ randomly placed along transects in the salt marsh and in the mudflat, at each location and season. Once each frame was placed on the ground, crabs on the surface or escaping from burrows were rapidly collected; later, each burrow was carefully dug up to take all the crabs that remained inside. This method has been extensively used for sampling $N$. granulata, being highly efficient in retrieving all crabs from burrows (Spivak et al. 1994; Bas et al. 2005; Méndez Casariego et al. 2011b).

Crabs captured in traps and in quadrats were measured (maximum carapace width, $\mathrm{CW}$ ) and sexed, and the presence of ovigerous females was registered. They were named "trap crabs" and "quadrat crabs," respectively. All individuals were returned to their original area. Size frequency distributions (SFD) and sex ratio were obtained from trap crabs collected in each habitat (mudflat, salt marsh and the border between them) and from quadrat crabs collected in mudflats and salt marshes.

A $\chi^{2}$ contingency table was used to compare sex ratios, a goodness of fit test of $\chi^{2}$ to evaluate differences among SFDs and a $Z$ test of comparison of proportions to evaluate the ratio ovigerous/non-ovigerous females between trap and quadrat crabs (Zar 2009). Only crabs larger than $18 \mathrm{~mm} \mathrm{CW}$ (Mar Chiquita) and $14 \mathrm{~mm} \mathrm{CW}$ (San Antonio and Bahía Blanca) collected in quadrats were used for comparisons; smaller crabs were discarded since they were never present in traps. 


\section{Results}

Frequency of habitat submersed by tides

The observations of actual events of emersion and submersion of each habitat during a complete tidal cycle showed differences among sites. In Mar Chiquita, the salt marsh was submerged only once during the only spring high tide sampled; in winter, the mudflat remained emerged during 5 out of 16 high tides (Fig. 4). In Bahía Blanca, instead, the salt marsh remained emerged in two and the mudflat in five out of the 16 sampled high tides (Fig. 5). The highest regularity of submersion occurred in San Antonio where high tides always submerged both sampled areas (Fig. 6).

Physical conditions of burrows, air and water

In Bahia Blanca, burrows dug in the lower salt marsh had almost no structure; they frequently collapsed when the measuring instrument was introduced. Burrows in the mudflat, instead, were well structured and very deep $(50 \mathrm{~cm}$ or more) reaching in some cases the water table. In the bare intertidal zone of San Antonio, sediment consisted of cobbles and coarse sand where water percolated easily, so burrows were dry shortly after the tide began to recede. In the salt marsh, where some fine sediment accumulated, water was retained for longer periods, and in some occasions, it persisted until the next tidal cycle.

Temperature and salinity of water in burrows varied greatly with site, season and air temperature (Tables 2 and 3). In Mar Chiquita, the daily and seasonal ranges of $T_{\text {burrow }}$ were narrower than the range of $T_{\text {air }}$ in both habitats, and the difference was more noticeable in the salt marsh ( $t$ test, $t=8.11, p<0.01 ; t$ test, $t=4.22, p<0.05$, mudflat and salt marsh, respectively, Table 2). In Bahía Blanca, there were no differences between the ranges of $T_{\text {burrow }}$ and $T_{\text {air }}$ ( $t$ test, $t=0.57, p=0.3 ; t$ test, $t=0.44$, $p=0.34$, mudflat and salt marsh, respectively, Table 2). In San Antonio, the range of $T_{\text {burrow }}$ was narrower than the range of $T_{\text {air }}$ in the salt marsh but not in the mudflat ( $t$ test, $t=4.41, p<0.05$ and $t=0.67, p=0.27$, respectively, Table 2).

Water salinity inside burrows differed between sites and habitats. Mar Chiquita was the only site where salinities below normal seawater were recorded (minimum value $10 \%$ ) and the maximum value observed $(47 \%$ ) was lower than in the other sites (Table 3). In Bahía Blanca, it ranged between full marine and hypersaline conditions, especially in mudflat burrows (34-63\%, Table 3). Similar conditions were observed in San Antonio: $35-46 \%$ and $36-54 \%$ in salt marsh and mudflat, respectively (Table 3). There were no significant differences in the mean $S$ ranges in Bahía Blanca ( $t$ test, $t=1.19, p=0.15$ ), and Mar Chiquita ( $t$ test,
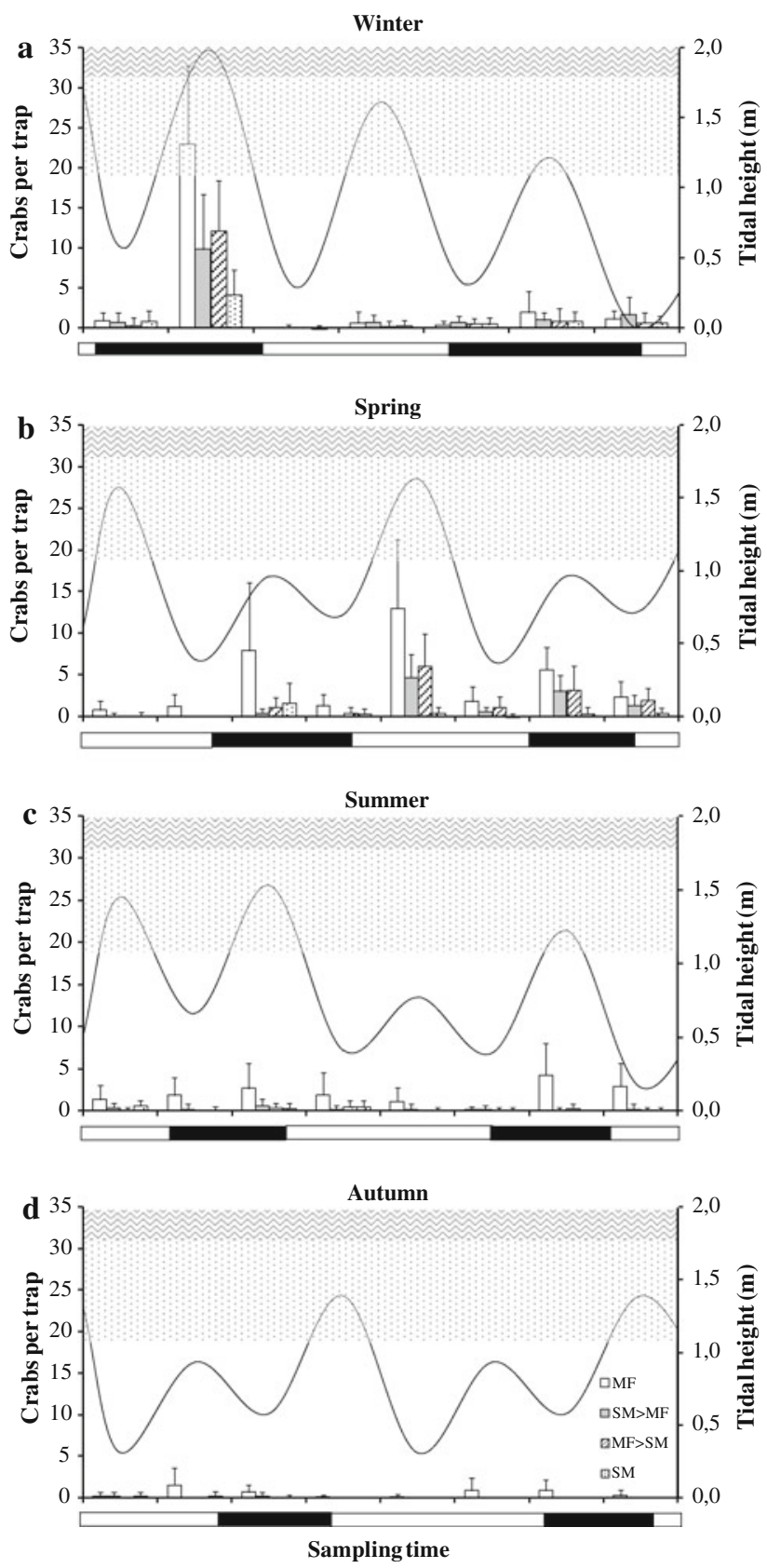

Fig. 4 Average number $( \pm S D)$ of crabs per trap collected after each flood and ebb tide throughout $48 \mathrm{~h}$ in Mar Chiquita in winter (a), spring (b), summer (c) and autumn (d). Crabs trapped in mudflat (MF), salt marsh (SM) and those collected moving from salt marsh to mudflat $(\mathrm{SM}>\mathrm{MF})$ and from mudflat to salt marsh $(\mathrm{MF}>\mathrm{SM})$ are shown. Tidal height is superimposed as a continuous line. Dotted shadow indicates tidal height covering the MF; waved shadow indicates tidal height covering the SM. Horizontal bars below each graph indicate periods of daylight (white) and darkness (black)

$t=1.8, p=0.08$ ) (Table 3) but they were smaller in salt marsh than in mudflat burrows in San Antonio ( $t$ test, $t=2.97, p<0.05$ ).

The relative humidity of the air was not different between habitats $\left(F_{(2,1068)}=129.1 ; p=0.26\right)$ but differed 

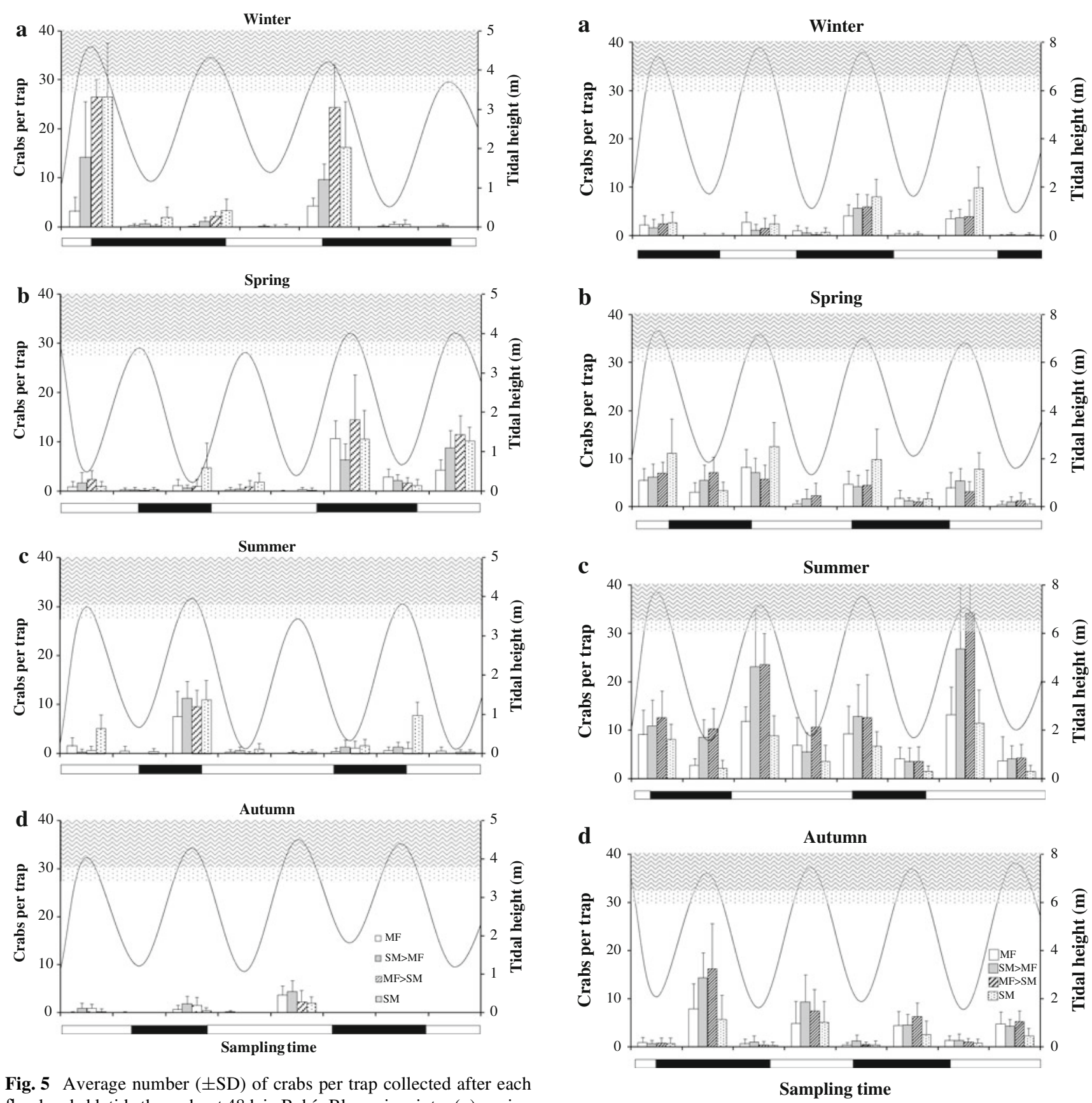

flood and ebb tide throughout $48 \mathrm{~h}$ in Bahía Blanca in winter (a), spring (b), summer (c) and autumn (d). See explanations in caption under Fig. 4

among sites $\left(F_{(2,1068)}=1.25 ; p<0.001\right)$. It decreased from Mar Chiquita to San Antonio. As an example, $52 \%$ of measurements taken after ebb tides in the mudflat of Mar Chiquita yielded values $\geq 80 \%$ relative humidity, and only $7 \%$ of the measured values had $\leq 60 \%$ relative humidity. In San Antonio, the respective proportions of high and low humidity were 12.5 and $47 \%$. The values observed in Bahía Blanca were intermediate between both sites.

Fig. 6 Average number $( \pm S D)$ of crabs per trap collected after each flood and ebb tide throughout $48 \mathrm{~h}$ in San Antonio in winter (a), spring (b), summer (c) and autumn (d). See explanations in caption under Fig. 4

General crab behavior

In winter, crabs collected from burrows during ebb tides with temperatures below $10{ }^{\circ} \mathrm{C}$ were motionless; however, when burrows or traps were covered by water, they turned active and fast moving, even at temperatures as low as $2{ }^{\circ} \mathrm{C}$. In autumn, in Mar Chiquita and Bahía 
Table 2 Range and $\Delta \mathrm{T}^{\circ}$ of air temperature ( $\mathrm{T}^{\circ}$ air) and water temperature from burrows of Neohelice granulata $\left(\mathrm{T}^{\circ}\right.$ burrow) in mudflat and salt marsh in three sites, Mar Chiquita, Bahía Blanca and San Antonio Bay, and four seasons (winter, spring, summer and autumn)

\begin{tabular}{|c|c|c|c|c|c|c|c|c|c|}
\hline \multirow[t]{2}{*}{ Site } & \multirow[t]{2}{*}{ Season } & \multicolumn{4}{|l|}{ Mudflat } & \multicolumn{4}{|l|}{ Salt marsh } \\
\hline & & $\mathrm{T}^{\circ}$ air & $\Delta \mathrm{T}^{\circ}$ & $\mathrm{T}^{\circ}$ burrow & $\Delta \mathrm{T}^{\mathrm{o}}$ & $\mathrm{T}^{\circ}$ air & $\Delta \mathrm{T}^{\circ}$ & $\mathrm{T}^{\circ}$ burrow & $\Delta \mathrm{T}^{\circ}$ \\
\hline \multirow[t]{5}{*}{ Mar Chiquita } & Winter & $14.7-0.7$ & 15.4 & $14.9-2.6$ & 12.3 & $13.6-0.4$ & 13.2 & 11.9-1.4 & 10.5 \\
\hline & Spring & $26.1-11$ & 15.1 & $24.6-14.2$ & 10.4 & $28.2-12.1$ & 16.1 & $21.3-16.4$ & 4.9 \\
\hline & Summer & $31.7-16.3$ & 15.4 & $27.3-17.1$ & 10.2 & $32.1-16.2$ & 15.9 & & 5.9 \\
\hline & Autumn & $15.3-2.7$ & 12.6 & $12.2-3$ & 9.2 & $16.8-2.7$ & 14.1 & $8.9-6.7$ & 2.2 \\
\hline & Mean, SD & & 14.6, 1.3 & & $10.5,1.3$ & & $14.8,1.4$ & & $5.8,3.4$ \\
\hline \multirow[t]{5}{*}{ Bahía Blanca } & Winter & $9.8-0.6$ & 9.2 & $11-0.3$ & 10.7 & $9.9-0.4$ & 9.5 & $10.3-0.8$ & 9.5 \\
\hline & Spring & $31.6-19.5$ & 12.1 & $29.1-15.8$ & 13.3 & $33.3-19.4$ & 13.9 & $27.3-15.9$ & 11.4 \\
\hline & Summer & $28.5-17.6$ & 10.9 & $25-15.6$ & 9.4 & $30.1-18.2$ & 11.9 & $31-15.9$ & 15.1 \\
\hline & Autumn & $15.4-1.9$ & 13.5 & $13.7-4.5$ & 9.2 & $15.2-3.5$ & 11.7 & $14.1-5.7$ & 8.4 \\
\hline & Mean, SD & & $11.4,1.8$ & & $10.6,1.8$ & & $11.7,1.7$ & & $11.1,2.9$ \\
\hline \multirow[t]{5}{*}{ San Antonio } & Winter & $14.8-5.4$ & 9.4 & $13.7-4.2$ & 9.5 & $15.2-3.8$ & 11.4 & $13.1-4.4$ & 8.7 \\
\hline & Spring & $28.9-18.2$ & 10.7 & $24.9-134$ & 11.5 & $31.6-18.8$ & 12.8 & $22.4-18.6$ & 3.8 \\
\hline & Summer & $35.7-18.4$ & 17.3 & $32.4-15.4$ & 17 & $38.5-17.5$ & 21 & $30.2-19.4$ & 10.8 \\
\hline & Autumn & $23.2-6.1$ & 17.1 & $21.1-6.6$ & 14.5 & $24.8-5.1$ & 19.7 & $19.1-10$ & 9.1 \\
\hline & Mean, SD & & $13.6,4.1$ & & $13.1,3.3$ & & $16.2,4.8$ & & $8.1,3$ \\
\hline
\end{tabular}

Bold types indicate significant differences among mean $\Delta \mathrm{T}^{\circ}$ between air and burrows $(t$ test, $p<0.05)$

Table 3 Range and $\Delta S^{\circ}$ of salinity of water from burrows of Neohelice granulata ( $\mathrm{S}^{\circ}$ burrow) in mudflat and salt marsh in three sites Mar Chiquita, Bahía Blanca and San Antonio Bay, and four seasons (winter, spring, summer and autumn)

\begin{tabular}{|c|c|c|c|c|}
\hline & \multicolumn{2}{|l|}{ Mudflat } & \multicolumn{2}{|l|}{ Salt marsh } \\
\hline & $\mathrm{S}^{\circ}$ burrow & $\Delta \mathrm{S}$ & $\mathrm{S}^{\circ}$ burrow & $\Delta \mathrm{S}$ \\
\hline \multicolumn{5}{|c|}{ Mar Chiquita } \\
\hline Winter & $40-27$ & 13 & $40-32$ & 8 \\
\hline Spring & $45-32$ & 13 & $47-32$ & 15 \\
\hline Summer & $40-10$ & 30 & $40-26$ & 14 \\
\hline Autumn & $34-21$ & 13 & $35-30$ & 5 \\
\hline Mean, SD & & $17.2,8.5$ & & $10.5,4.8$ \\
\hline \multicolumn{5}{|c|}{ Bahía Blanca } \\
\hline Winter & $40-34$ & 6 & $40-33$ & 7 \\
\hline Spring & $45-35$ & 10 & $51-40$ & 11 \\
\hline Summer & $63-50$ & 13 & $57-42$ & 15 \\
\hline Autumn & $40-35$ & 5 & $38-34$ & 4 \\
\hline Mean, SD & & $8.5,3.7$ & & $9.2,4.8$ \\
\hline \multicolumn{5}{|l|}{ San Antonio } \\
\hline Winter & $42-36$ & 6 & $40-35$ & 5 \\
\hline Spring & $52-40$ & 12 & $46-39$ & 7 \\
\hline Summer & $54-37$ & 17 & $43-36$ & 7 \\
\hline Autumn & $50-37$ & 13 & $43-36$ & 7 \\
\hline Mean, SD & & $12,4.5$ & & $6.5,1$ \\
\hline
\end{tabular}

Bold types indicate significant differences among mean $\Delta S^{\circ}$ between mudflat and salt marsh $(t$ test, $p<0.05)$
Blanca, the entrances of many burrows were closed with mud, and crabs inside were in pre- and post-molt. During spring and summer ebb tides in Mar Chiquita and Bahía Blanca, most crabs were near the entrances of burrows while they were full of water, moved inside as soon as they were getting drier and stayed in the burrows during the ebbing period. In San Antonio, instead, many crabs picked up and ate sediment immediately after the tide receded, not only when the sediment remained wet at night, but also during the day.

Relationship of activity with season, tide, habitat and diurnal phase

Mar Chiquita: Due to irregular flooding (see above), the tidal effect was not tested. Crab activity was almost null in autumn and thus it was not considered in the analysis afterward (Fig. 4). Crabs moved more within the mudflat (even when they were not covered by water) than between habitats or within the salt marsh, except in few winter samples with very low activity (Fig. 4). There was interaction among habitat, season and diurnal phase $\left(\chi^{2}=26.24, p<0.001\right)$, and the a posteriori comparisons showed that more crabs moved in the mudflat than in the salt marsh, except during the day in winter (Online Resource: Table S1 and Fig S1).

Bahía Blanca: As in Mar Chiquita, crabs were rarely active during autumn; thus, this season was not considered 
in the subsequent analysis. In spring and summer, the activity was similar within and between habitats, but in winter, crabs moved more between habitats (Fig. 5). Not all diurnal phase conditions occurred at every tidal condition in both habitats so the effect of diurnal phase was not evaluated in the analysis. There was no interaction among season (winter, spring and summer), habitat and tide. Nevertheless, all pairs of factors interacted (season $\mathrm{x}$ habitat, $\chi^{2}=33.87$, $p<0.001$; season $\times$ tide, $\chi^{2}=23.92, p<0.001$; habitat $\mathrm{x}$ tide, $\chi^{2}=11.79, p<0.001$; Online Resource: Table S2 and Fig. S2). Crab movements were more intense during floods in both habitats. In winter, crabs were active at every other high tide instead of after each flooding, in accordance with daylight high tides, and they were significantly more active in the salt marsh.

San Antonio: Crabs were active during all seasons. Maximum activity was observed in summer and minimum in winter. More crabs were caught at the border between habitats (moving in both directions) in summer and autumn (Fig. 6). There were significant interactions among season, habitat and tide and among season, diurnal phase and tide $\left(\chi^{2}=10.23, \quad p<0.05 ; \quad \chi^{2}=31.19\right.$, $p<0.001$, respectively; Online Resource: Table S3 and Fig. S3). In autumn and winter, the activity was always higher during flood tides in both habitats and almost null during ebb tides. In spring and summer, crabs were active even when they were uncovered by water. In spring, during low tide, the activity was higher at night. In summer, crabs moved more intensely during floods in the salt marsh while the difference between tidal phases was not significant in the mudflat.

Sex and size of active crabs

Size frequency distributions differed between traps and quadrats, except for females in the Mar Chiquita mudflat (Fig. 7; Goodness of fit test). Although only large crabs ( $>18 \mathrm{~mm} \mathrm{CW}$ in Mar Chiquita and $>14 \mathrm{~mm} \mathrm{CW}$ in San Antonio and Bahía Blanca) were found in pitfall traps in all sites and habitats, small individuals represented an important part of the quadrat samples (e.g., Mar Chiquita salt marsh, Fig. 7). Sex ratios in traps were strongly biased given that at least $70 \%$ of trapped crabs were males (excepting Bahía Blanca mudflat); they differed from the sex ratio in quadrats (1:1 or slightly male biased) excepting Bahía Blanca mudflat and Mar Chiquita salt marsh (Fig. 7, $Z$ test, Table 4). There were no differences in size structure among crabs trapped in mudflats, salt marshes or in the interface between habitats $\left(\chi^{2}\right.$ contingency table, paired comparisons, all $p>0.05$ ). Ovigerous females were present in spring and summer in variable proportions in different populations and were always more abundant in salt marshes. The proportion of ovigerous females in traps was lower than in quadrats (Fig. 8); these differences were highest in San Antonio $(Z=3.3$ and $Z=6.9, p>0.001$ mudflat and salt marsh, respectively) and also significant in the mudflat of Mar Chiquita $(Z=2.3, p>0.05)$. In Bahía Blanca and in the salt marsh of Mar Chiquita, the differences were not significant; nevertheless, the power of the tests was low.

\section{Discussion}

The southwestern Atlantic burrowing crab Neohelice granulata has different activity patterns: the well-studied short and brief field exploratory movements (Fathala et al. 2010a, b), the movements within and between habitats (this paper), and the proposed reproductive migrations of ovigerous females that release larvae in shallow waters during high tides (Anger et al. 1994).

Movement within and between habitats was performed mainly by large crabs, predominantly males (sex ratio in traps was 5 males: 1 female) as had also been observed in Chasmagnathus convexus (Nakasone et al. 1982). This should represent a true difference in displacement range between sexes and size groups and not a methodological artifact (e.g., females and juveniles avoid traps more efficiently than males) because most active crabs observed in the field were large males or, to a lesser extent, large females (unpublished observations). Ovigerous females were captured much less frequently than non-ovigerous females, suggesting that activity also depends on the reproductive condition. Juveniles were not found in traps: they usually concentrate in salt marshes, protected by the higher structural complexity of this habitat and remain near the entrance of adult burrows (Spivak et al. 1994, Bas et al. 2005, Luppi et al. 2002). Similar differences between crab size and sex were observed during the intertidal migrations of Carcinus maenas: males moved farther than females and non-ovigerous females moved more than ovigerous ones (Hunter and Naylor 1993). In N. granulata, this behavioral diversity could be related to the vulnerability to predators of each sex (due to the great difference in chelae size), to the susceptibility of small crabs to be cannibalized by larger males (Luppi et al. 2001) and/or to the higher susceptibility of small crabs to extreme temperature and water loss (Willmer et al. 2000; Méndez Casariego et al. 2011a).

Neohelice granulata was active over a range of temperatures, salinity and humidity that were wider than those reported for other species with similar characteristics (Bliss et al. 1978; Goshima et al. 1978; Nakasone et al. 1982) but these variables interacted in a complex way and were also affected by other studied (e.g., tides, burrow structure) or unstudied (e.g., predation pressure) environmental factors. 

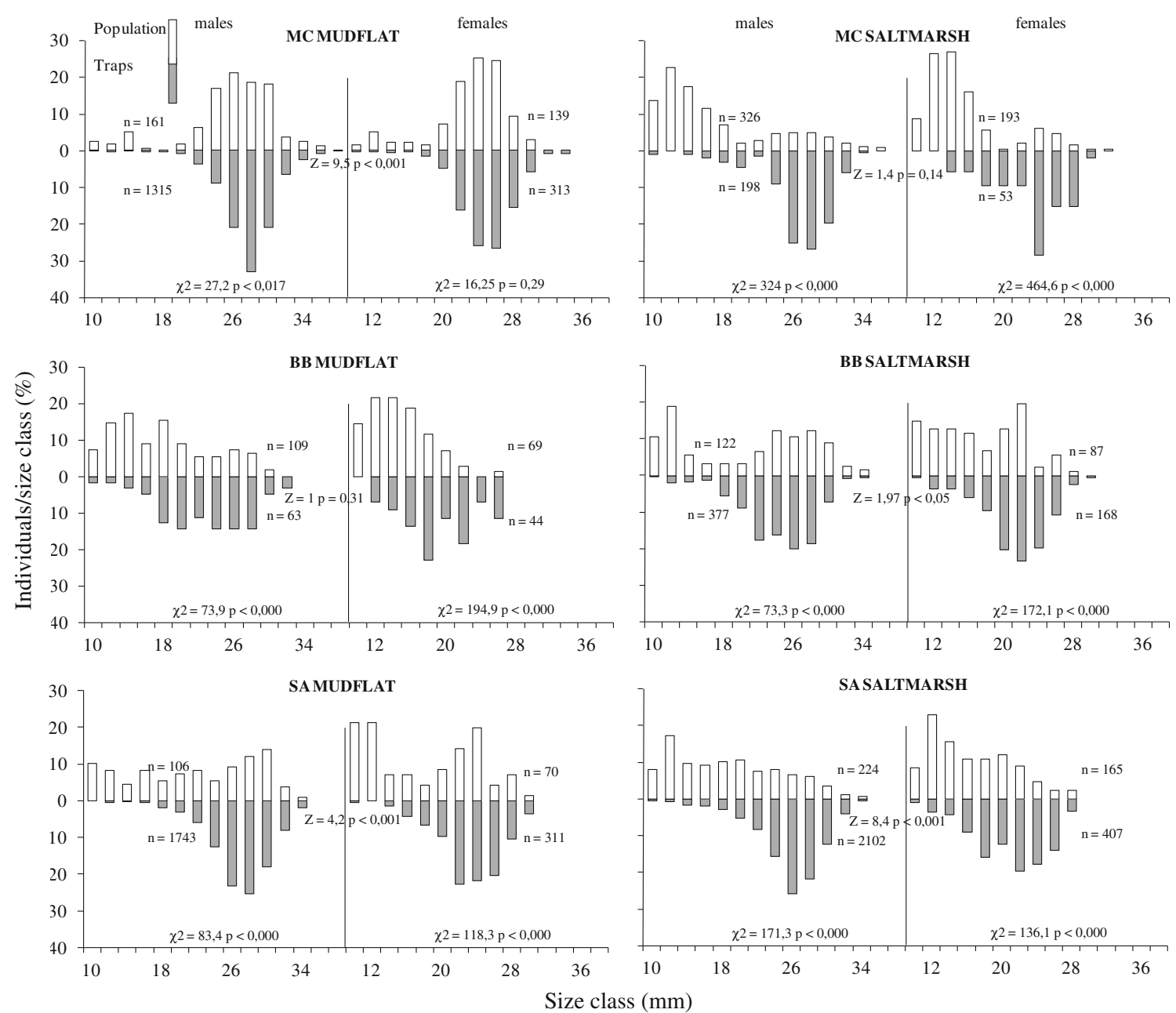

Fig. 7 Size frequency distribution (SFD) of males and females collected from quadrats (white bars, population samplings) and traps (gray bars) in salt marshes and mudflats of $M C$ Mar Chiquita, $B B$ Bahía Blanca and $S A$ San Antonio (all seasons pooled). $\chi^{2}$ : statistic of
Chi-square test to compare SFD of population and traps. Z: statistic of $z$ test to compare proportions of males in populations and in traps. $p$ : significance of tests. To compute $Z$ test, only crabs $>18 \mathrm{~mm} \mathrm{AC} \mathrm{in}$ $\mathrm{MC}$ and $>14 \mathrm{~mm} \mathrm{AC}$ in $\mathrm{SA}$ and $\mathrm{BB}$ were considered
Table 4 Numbers of males and females (carapace width $>10 \mathrm{~mm}$ ) collected in traps and in population surveys, in mudflat and salt marsh, and in three sites: Mar Chiquita, Bahía Blanca and San Antonio Bay

\begin{tabular}{|c|c|c|c|c|c|c|}
\hline & \multicolumn{3}{|c|}{ Mudflat } & \multicolumn{3}{|c|}{ Salt marsh } \\
\hline & Males & $\chi^{2}, p$ & Females & Males & $\chi^{2}, p$ & Females \\
\hline \multicolumn{7}{|l|}{ Mar Chiquita } \\
\hline Traps & 1,315 & $338.6 * * *$ & 315 & 199 & $46.1 * * *$ & 53 \\
\hline Population & 161 & $0.8 \mathrm{~ns}$ & 139 & 326 & $17.5 * * *$ & 193 \\
\hline \multicolumn{7}{|l|}{ Bahía Blanca } \\
\hline Traps & 63 & $1.5 \mathrm{~ns}$ & 44 & 377 & $41.2 * * *$ & 168 \\
\hline Population & 109 & $4.55^{*}$ & 69 & 122 & $2.7 \mathrm{~ns}$ & 87 \\
\hline \multicolumn{7}{|l|}{ San Antonio } \\
\hline Traps & 1,743 & $568.2 * * *$ & 311 & 2,102 & $645.6 * * *$ & 407 \\
\hline Population & 106 & $3.7 \mathrm{~ns}$ & 70 & 224 & $4.3 *$ & 165 \\
\hline
\end{tabular}

$\chi^{2}:$ statistics of Chi-square test, $* * * p<0.001, * * p<0.01$, $* p<0.05$, ns non-significant also collected in traps after low tides in summer, with temperatures above $31{ }^{\circ} \mathrm{C}$ and humidity below $45 \%$, suggesting that the underwater activity is not only related with harsh conditions at low tide. $N$. granulata was considered
In addition, the activity differed among sites, tidal height and season.

The activity of crabs was, in general, higher during the high tide phase. However, crabs from San Antonio were 


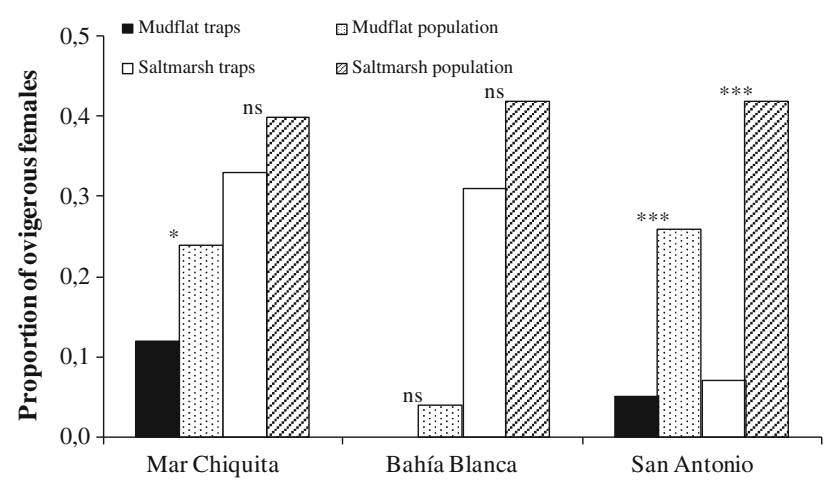

Fig. 8 Proportions of ovigerous females collected from traps and quadrats in mudflat and salt marsh, in Mar Chiquita, Bahía Blanca and San Antonio. ${ }^{* * *} p<0.0001,{ }^{*} p<0.05, n s$ non-significant for $Z$ test

inactive during winter (D'Incao et al. 1988). This is true for crabs collected in dry burrows at temperatures of $10{ }^{\circ} \mathrm{C}$ or lower; nevertheless, they became completely active when covered by water, even at temperatures as low as $2{ }^{\circ} \mathrm{C}$. As far as we know, this is the first report of a semiterrestrial crab active at very low temperatures (albeit under water). The available information indicates that most land crabs are restricted to the tropics and subtropics; in temperate zones, they remain in burrows during winter, and it has been suggested that the shortening of the active season may explain their absence at higher latitudes (Wolcott 1988). Consequently, the tolerance to low temperatures may help to understand why $N$. granulata is one of the few semiterrestrial crabs that reaches latitudes higher than $40^{\circ} \mathrm{S}$ in the southern hemisphere (at least, it is the southernmost latitude in America).

Burrowing activity, tidal pattern, and food availability may explain the differences in moving activity observed among sites. The burrowing activity is widespread among crabs from intertidal soft-bottom habitats and provides a refuge from subtidal or aerial predators (Warren 1990; Fathala et al. 2010a, b). Even when the morphology of burrows is species-specific (Griffis and Suchanek 1991), it can vary intraspecifically in relation to trophic modes, sediment type, tidal level, water table depth, and structures on and under soil (Iribarne et al. 1997; Katrak et al. 2008; Sal Moyano et al. in press). The tidal pattern of each site results from different amplitudes and regularity of submersion events. Two main food resources consumed by estuarine and salt marsh crabs such as $N$. granulata are organic matter in the sediment and live plants (Iribarne et al. 1997; Alberti et al. 2007b).

The highest activity of crabs was registered in San Antonio. The low organic matter content in the sediment implies that food is not available inside or around burrows and it could be a factor forcing crabs to use living plants of $S$. alterniflora as food, and move intensely between mudflat and salt marsh. Burrows dug in the very coarse sediment are barely deep enough to host a crab; they get completely dry during low tide in the mudflat, although they remain humid in the salt marsh. In addition, tides that regularly (every $12 \mathrm{~h}$ ) cover the entire intertidal zone restore the salinity and temperature conditions allowing crabs to cope with this extreme environment. The lowest activity was observed in Mar Chiquita, considering all the environmental conditions examined, in both habitats and in all seasons. Tidal cycles in this site were very irregular, and the salt marsh was rarely covered by water, but at the same time, the organic matter content of the sediment was the highest making food always available inside and around burrows. Burrows are complex, deep and well structured especially in the salt marsh (Iribarne et al. 1997); crabs have a continuous supply of water (from the table water) and experience less variation in temperature and salinity. An intermediate activity was observed in Bahía Blanca, a site with intermediate tidal regularity and burrow depth, but with high organic matter content.

In addition, it is well known that predation affects the movements of intertidal crabs (Bertness 1999; Christy 2007 and cites herein). In the laboratory, adult males of $N$. granulata are responsive to a simulated aerial predator (Oliva et al. 2007 and references therein). In Mar Chiquita, $N$. granulata face an intense predation pressure from several birds, being the main prey of Larus atlanticus (Biondi et al. 2005; Sánchez et al. 2008; Berón et al. 2011). In any case, these predators are a very frequent threat in this site, particularly in the mudflat, where remains of crabs eaten by birds are commonly found. No predation studies are available in Bahía Blanca, but the higher level of activity of $N$. granulata in San Antonio could be related to the fact that, in contrast with the other two sites, L. atlanticus is not present (Yorio et al. 2005) allowing crabs to move safer. In fact, site differences in escape response have been reported recently: crabs from San Antonio are less reactive to a visual danger stimulus than those from Mar Chiquita (Magani et al. 2011).

Seasonal changes in activity also differed among sites. Crabs were almost inactive during autumn in Mar Chiquita and Bahía Blanca, independently of the daily variation in environmental conditions; they resume their movements in winter even though burrow temperatures reached the lowest values during this period $\left(2.6\right.$ and $0.3{ }^{\circ} \mathrm{C}$, respectively). Interestingly, crabs were similarly active in autumn and summer in San Antonio and the decrease in activity was observed in winter, although the minimum burrow temperatures were not so extreme $\left(4.2^{\circ} \mathrm{C}\right)$. A relationship between inactivity and molting could be hypothesized: many preand post-molt crabs were found inside closed burrows in autumn in Mar Chiquita and Bahía Blanca suggesting a rather synchronized molting season; autumn, instead, was 


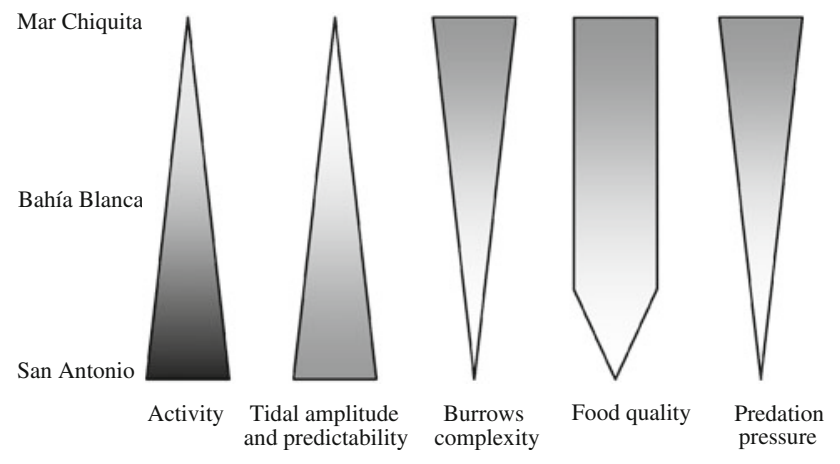

Fig. 9 Schematic representation of the combination of levels in the physical and biological factors associated with the activity level in each site

not the molting season in San Antonio (personal observations).

Summarizing, movement activity of $N$. granulata varied both in space and in time, and several environmental factors may affect them but interacting in a very complex way. In fact, a single factor could not explain all the observed patterns: crabs could move under very different conditions (e.g., low or high tide, during daylight or night, low and high temperature), and movements, instead, could be prevented or elicited by a combination of different levels of those factors and others, like burrow complexity, food quality and predation pressure (Fig. 9).

Acknowledgments This project was supported by the Universidad Nacional de Mar del Plata (EXA 440), ANPCyT (Argentina PICT 21757) granted to E.S., and ANPCyT (PICT 01272) and CONICET (Argentina PIP 5669; PIP 112-200801-00174) granted to O.I., A.M.C., M.A., J.L. and N.F. were supported by Doctoral scholarship from CONICET (Argentina), A.R. was supported by Doctoral scholarship from ANPyCT (Argentina). Authors deeply thank the suggestions of four anonymous referees and the detailed comments and criticisms of the editor M. Thiel.

\section{References}

Abele L, Campanella P, Salmo M (1986) Natural history and social organization of the semiterrestrial grapsid crab Pachygrapsus transverses (Gibbes). J Exp Mar Biol Ecol 104:153-170

Abelló P, Reid D, Naylor E (1991) Comparative locomotor activity patterns in the portunid crabs Liocarcinus holsatus and L. depurator. J Mar Biol Ass UK 71:1-10

Alberti J, Montemayor D, Alvarez F, Méndez Casariego A, Luppi T, Canepuccia A, Isaach JP, Iribarne O (2007a) Changes in rainfall pattern affect crab hervibory rates in a SW Atlantic salt marsh. J Exp Mar Biol Ecol 353:126-133

Alberti J, Escapa M, Daleo P, Iribarne O, Silliman B, Bertness M (2007b) Local and geographic variation in grazing intensity by herbivorous crabs in SW Atlantic salt marshes. Mar Ecol Prog Ser 349:235-243

Anger K, Spivak E, Bas C, Ismael D, Luppi T (1994) Hatching rhythms and dispersion of decapod crustacean larvae in a brackish coastal lagoon in Argentina. Helgoländer Meeresunters 48:445466
Bas C, Luppi T, Spivak E (2005) Population structure of the South American Estuarine crab, Chasmagnathus granulatus (Brachyura: Varunidae) near the southern limit of its geographical distribution: comparison with northern populations. Hydrobiologia 537:217-228

Batie R (1983) Rhythmic locomotor activity in the inter tidal shore crab Hemigrapsus oregonensis (Brachyura: Grapsidae) from the Oregon Coast USA. Northwest Sci 57:49-56

Berón P, García G, Luppi T, Favero M (2011) Age-related prey selectivity and foraging efficiency of Olrog's Gulls (Larus atlanticus) feeding on crabs in their non-breeding grounds. Emu 111:172178

Bertness M (1999) The ecology of the Atlantic shorelines. Sinauer, Sunderland

Biondi L, Bo S, Favero M (2005) Dieta del Chimango (Milvago chimango) durante el periodo reproductivo en el sudeste de la Provincia de Buenos Aires, Argentina. Ornit Tropical 16:31-42

Bliss D, Van Montfrans J, Van Montfrans M, Boyer J (1978) Behavior and growth of the land crab Gecarcinus lateralis (Freminville) in southern Florida. Bull Amer Mus Nat Hist 160:113-151

Bortolus A, Iribarne O (1999) Effect of the SW Atlantic Burrowing crab Chasmagnathus granulata on Spartina saltmarsh. Mar Ecol Prog Ser 178:79-88

Boschi E (1964) Los crustáceos decápodos Brachyura del litoral bonaerense. Bol Inst Biol Mar 164:1-34

Botto F, Iribarne O (1999) Effect of the burrowing crab Chasmagnathus granulata (Dana) on the benthic community of a SW Atlantic coastal lagoon. J Exp Mar Biol Ecol 241:263-284

Breitfuss M (2003) Defining the characteristics of burrows to better estimate abundance of the grapsid crab, Helograpsus haswellianus (Decapoda, Grapsidae), on east Australian marsh. Crustaceana 76:499-507

Brockerhoff A, McLay C (2005) Comparative analysis of the mating strategies in grapsid crabs with special references to the intertidal crabs Cyclograpsus lavauxi and Helice crassa (Decapoda: Grapsidae) from New Zealand. J Crust Biol 25:507-520

Brousseau D, Baglivo J, Filipowicz A, Sego L, Alt C (2002) An experimental field study of site fidelity and mobility in the Asian shore crab, Hemigrapusus sanguineus. Northeastern Nat 9:381-390

Cannicci S, Paula J, Vannini M (1999) Activity pattern and spatial strategy in Pachygrapsus marmoratus (Decapoda: Grapsidae) from Mediterranean and Atlantic shores. Mar Biol 133:429-435

Christy J (2007) Predation and the reproductive behavior of fiddler crabs (genus Uca). In: Thiel M, Duffy J (eds) Evolution of Social Behavior of Crustaceans. Oxford University Press, Oxford, pp 211-231

D’Incao F, Ruffino M, Da Silva K (1988) Notas preliminares sobre a ecologia de Chasmagnathus granulata Dana 1851 na barra de Rio Grande, RS. (Decapoda, Grapsidae). In Resumes XV Congresso Brasileiro de Zoologia, Curitiba

D'Incao F, Ruffino M, Da Silva K, Da Costa Braga A (1992) Responses of Chasmagnathus granulata Dana (Decapoda: Grapsidae) to salt-marsh environmental variations. J Exp Mar Biol Ecol 161:179-188

Dumas J, Witman J (1993) Predation by gulls on two rocky intertidal crabs, Cancer irroratus and Carcinus maenus. J Exp Mar Biol Ecol 169:89-101

Escapa M, Minkoff D, Perillo G, Iribarne O (2007) Direct and indirect effects of burrowing crab Chasmagnathus granulatus activities on erosion of southwest Atlantic Sarcocornia-dominated marshes. Limnol Oceanogr 52(6):2340-2349

Eshky A (1999) Physiological adaptation of the amphibious rocks crab Grapsus tenuicrustatus from the Red Sea. J King Abdulaziz Univ Mar Sci 10:109-124

Fanjul E, Grela A, Canepuccia A, Iribarne O (2008) The Southwest Atlantic intertidal burrowing crab Neohelice granulata modifies 
nutrient loads of phreatic waters entering coastal area. Est Coast Shelf Sci 79:300-306

Fathala M, Iribarren L, Kunert M, Maldonado H (2010a) A field model of learning: 1. Short-term memory in the crab Chasmagnathus granulatus. J Comp Physiol A 196:61-75

Fathala M, Kunert M, Maldonado H (2010b) A field model of learning: 2. Long-term memory in the crab Chasmagnathus granulatus. J Comp Physiol A 196:77-84

Ferreira Silva A, Brazao S, Hawkins S, Thompson R, Boaventura D (2009) Abundance, population structure and claw morphology of the semi-terrestrial crab Pachygrapsus marmoratus (Fabricius, 1787) on shores of differing wave exposure. Mar Biol 156:25912599

Fratini S, Cannicci S, Abincha L, Vannini M (2000) Feeding temporal and spatial preferences of Metopograpsus thukuhar (Decapoda; Grapsidae): an opportunistic mangrove dweller. J Crust Biol 20:326-333

Gerhard D, Schaarschmidt F, Hothorn L (2007) Simultaneous confidence intervals for overdispersed count data. In: Posch M, Hsu J, König F (eds) Abstracts from the 5th international conference on multiple comparison procedures. Vienna Austria, p 135

Goshima S, Ono Y, Nakasone Y (1978) Daily activity and movement of the land crab, Cardisoma hirtipes Dana, by radio-telemetry during non-breeding season. Publ Amakusa Mar Biol Lab 4(3): $175-187$

Griffis R, Suchanek T (1991) A model of burrow architecture and trophic modes in thalassinidean shrimp (Decapoda: Thalassinidae). Mar Ecol Prog Ser 79:171-183

Halperin J, Ansaldo M, Pellerano G, Luquet C (2000) Bimodal breathing in the estuarine crab Chasmagnathus granulatus (Dana 1851): physiological and morphological studies. Comp Biochem Physiol B126:341-349

Hartnoll R (2009) Sexual maturity and reproductive strategy of the rock crab Grapsus adscensionis (Osbeck, 1765) (Brachyura, Grapsidae) on Ascension Island. Crustaceana 82:275-291

Hiatt R (1948) The biology of the lined shore crab Pachygrapsus crassipes. Pac Sci 2:135-212

Hines H (2007) Ecology of juvenile and adult blue crabs. In: Kenney V, Cronin L (eds), The blue crab Callinectes sapidus. Maryland Sea Grant Collage, College Park, pp 565-654

Hunter E, Naylor E (1993) Intertidal migration by the shore crab Carcinus maenas. Mar Ecol Prog Ser 101:131-138

Iribarne O, Bortolus A, Botto F (1997) Between-habitat differences in burrow characteristics Atlantic burrowing crab Chasmagnathus granulata. Mar Ecol Prog Ser 155:137-145

Isacch J, Costa C, Rodríguez-Gallego L, Conde D, Escapa M, Gagliardini D, Iribarne O (2006) Distribution of saltmarsh plant communities associated with environmental factors along a latitudinal gradient on the south-west Atlantic coast. J Biogeogr 33:888-900

Ituarte R, Spivak E, Luppi T (2004) Female reproductive cycle of the Southwestern Atlantic estuarine crab Chasmagnathus granulatus (Brachyura, Grapsoidea, Varunidae). Sci Mar 68: 127-137

Katrak G, Dittmann S, Seuront L (2008) Spatial variation in burrow morphology of the mud shore crab Helograpsus haswellianus (Brachyura, Grapsidae) in South Australian saltmarshes. Mar Freshw Res 59:902-911

Kurihara Y, Sekimoto K, Miyata M (1988) Wandering behavior of the mud-crab Helice tridens related to evasion of cannibalism. Mar Ecol Prog Ser 49:41-50

Lohrer A, Fukui Y, Wada K, Whitlatch R (2000) Structural complexity and vertical zonation of intertidal crabs, with focus on habitat requirements of the invasive Asian shore crab, Hemigrapsus sanguineus (de Haan). J Exp Mar Biol Ecol 244:203-217

Luppi T, Spivak E, Anger K (2001) Experimental studies of predation and cannibalism in recruits of Chasmagnathus grannulata and
Cyrtograpsus angulatus (Brachyura: Grapsidae). J Exp Mar Biol Ecol 265:29-48

Luppi T, Spivak E, Anger K, Valero J (2002) Pattern and processes of Chasmagnathus granulata and Cyrtograpsus angulatus (Brachyura: Grapsidae) recruitment in Mar Chiquita Coastal Lagoon, Argentina. Est Coast Shelf Sci 55:287-297

Magani F, Luppi T, Tomsic D (2011) Predation risk may sculpt functional differences in identified brain neurons. Abstracts from the XXVI Congreso Anual de la Sociedad Argentina de Investigación en Neurociencia, Huerta Grande, Argentina

Maldonado H (2002) Crustaceans as models to investigate memory illustrated by extensive behavioral and physiological studies in Chasmagnathus. In: Wiese K (ed) The Crustacean Nervous System. Springer, Berlin, pp 526-535

Méndez Casariego A, Luppi T, Iribarne O, Daleo P (2011a) Increase of organic matter transport between marshes and tidal flats by the burrowing crab Neohelice (Chasmagnathus) granulata Dana in SW Atlantic salt marshes. J Exp Mar Biol Ecol 401:110-117

Méndez Casariego A, Alberti J, Luppi T, Daleo P, Iribarne O (2011b) Habitat shifts and spatial distribution of the intertidal crab Neohelice (Chasmagnathus) granulata Dana. J Sea Res. doi:10.1016/ j.seares.2011.05.001

Morgan S, Spilseth S, Page H, Brooks A, Grosholz E (2006) Spatial and temporal movement of the lined shore crab Pachygrapsus crassipes in salt marshes and its utility as an indicator of habitat condition. Mar Ecol Prog Ser 314:271-281

Nakasone Y, Ono Y, Goshima S (1982) Daily activity and food consumption of the sesarmid crab Chasmagnathus convexus (Decapoda, Brachyura). Bull College Educ (University of the Ryukyus) 26:37-53

Naylor E (2005) Chronobiology: implications for marine resource exploitation and management. Sci Mar 69(1):157-167

Ng P, Sivasothi N (2001) A guide to mangroves of Singapore. Raffles Museum of the Biodiversity Research. The National University of Singapore and The Singapore Science Centre

Oliva D, Medan V, Tomsic D (2007) Escape behavior and neuronal response to looming stimuli in the crab Chasmagnathus granulatus (Decapoda: Grapsidae). J Exp Biol 210:865-880

Omori K, Shiraishi K, Hara M (1997) Life histories of sympatric mudflat crabs, Helice japonica and H. tridens (Decapoda: Grapsidae), in a Japanese estuary. J Crust Biol 17:279-288

Palmer J (1967) Daily and tidal components in the persistent rhythmic activity of the crab Sesarma. Nature 215:64-66

Palmer J (1995) The biological rhythms and clocks of intertidal animals. Oxford University Press, Oxford

Piccolo MC, Perillo G (1997) Geomorfología e hidrografía de los estuarios. In: Boschi E (ed) El Mar Argentino y sus recursos pesqueros. Tomo 1. Antecedentes históricos de las exploraciones en el mar y las características ambientales. Publicaciones Especiales INIDEP, Mar del Plata, pp 133-161

R Development Core Team (2008) R: A language and environment for statistical computing. R Foundation for Statistical Computing, Vienna, Austria. ISBN 3-900051-07-0, URL http://www.Rproject.org

Romero L (2003) Comportamiento reproductivo y mutilaciones en el cangrejo de las rocas Grapsus grapsus (Linnaeus, 1758) (Crustacea, Decapoda). Rev Peru biol 10(2):195-202

Sal Moyano M, Gavio M, Luppi T (in press) Mating system of the burrowing crab Neohelice granulata (Brachyura: Varunidae) in two contrasting environments: effect of burrow architecture. Marine Biol. doi:10.1007/s00227-012-1917-6

Sánchez K, Malizia A, Bo S (2008) Trophic ecology of the burrowing owl (Athene cunicularia) in urban environments of Mar Chiquita biosphere reserva (Buenos Aires Province, Argentina). Ornit Neotr 19:71-80 
Seiple W (1979) Distribution, habitat preferences and breeding periods in the Crustaceans Sesarma cinereum and S. reticulatum (Brachyura: Decapoda: Grapsidae). Mar Biol 52:77-86

Seiple W (1981) The ecological significance of locomotor activity rhythms of Sesarma cinereum (Bosc) and Sesarma reticulatum (Say). Crustaceana 40:1-15

Seiple W, Mueller B (1992) Patterns of refuge use by Sesarma cinereum (Bosc). Bull Mar Sci 50(1):158-164

Snow P (1973) Ultrastructure of the aesthetasc hairs of the litoral decapod, Paragrapsus gaimardii. Zeitschrift für Zellforschung und Mikroskopische Anatomie 38:489-502

Spivak E (1999) Effects of reduced salinity on juvenile growth of two co-occurring congeneric grapsid crabs. Mar Biol 134:249-257

Spivak E (2010) The crab Neohelice (= Chasmagnathus) granulata: an emergent animal model from emergent countries. Helgol Mar Res 64:149-154

Spivak E, Anger K, Luppi T, Bas C, Ismael D (1994) Distribution and habitat preference of two grapsid crab species in Mar Chiquita Lagoon (Province of Buenos Aires, Argentina). Helgoländer Meeresunters 48:59-78

Thurman C (2004) Unravelling the ecological significance of endogenous rhythms in intertidal crabs. Biol Rhyt Res 35:43-67

Vannini M, Cannicci S (1995) Homing behaviour and possible cognitive maps in crustacean decapods. J Exp Mar Biol Ecol 193:67-91
Vannini M, Ruwa R, Cannicci S (1997) Effect of microclimatic factors and tide on vertical migrations of the mangrove crab Sesarma leptosoma (Decapoda: Grapsidae). Mar Biol 130:101-108

Warren J (1990) Role of burrows as refuge from subtidal predators of temperate mangrove crab. Mar Ecol Prog Ser 67:295-299

Willason S (1981) Factors influencing the distribution and coexistence of Pachygrapsus crassipes and Hemigrapsus oregonensis (Decapoda: Grapsidae) in California salt marsh. Mar Biol 64:125-133

Williams B, Naylor E, Chatterton T (1985) The activity patterns of New Zealand mud crabs under field and laboratory conditions. J Exp Mar Biol Ecol 89:269-282

Willmer P, Stone G, Johnston I (2000) Environmental physiology of animals. Blackwell Science, Oxford

Wolcott T (1988) Ecology. In: Burggren W, McMahon B (eds) Biology of the land crabs. Cambridge University Press, Cambridge, pp 55-96

Yorio P, Bertellotti M, García Borboroglu P (2005) Estado poblacional y de conservación de gaviotas que se reproducen en el Litoral marítimo Argentino. Hornero 20:53-74

Zar J (2009) Biostatistical analysis (fifth edition). Pearson International Edition, Upper Saddle River 